\title{
Verbi verbistä
}

\section{Puolan ja suomen johdetun verbileksikon merkitysrakenteen vertailua}

\author{
Anna Maija Biskupska
}

\section{Väitöksenalkajaisesitelmä Helsingin yliopistossa 3. maaliskuuta 2018}

Väitöskirjani hieman arvoituksellista nimeä Verbi verbistä ei pidä tulkita niin kuin Hammurabin lain periaatetta "silmä silmästä, hammas hampaasta" 'jos viet joltakulta silmän tai hampaan, sinulta viedään silmä tai hammas' vaan positiivisen vastavuoroisesti '(millainen on) suomen verbi puolan verbiä vastaan ja puolan verbi suomen verbiä vastaan'. Työn alaotsikko täsmentääkin, että on kyse puolan ja suomen johdetun verbileksikon merkitysrakenteen vertailusta.

Miksi sitten juuri suomen ja puolan vertailu? Taustalla on oma elämänhistoriani polonistisine ja fennistisine opintoineen sekä työurani, jonka kuluessa olen muun muassa opettanut sekä suomea puolalaisille Varsovan ja Krakovan yliopistoissa että puolaa suomalaisille Helsingin yliopistossa.

Lähes koko aikuiselämäni on jakautunut Puolan ja Suomen välille niin, että olen asunut suomalais-puolalaisen perheeni kanssa osan vuotta Suomessa ja osan Puolassa käyttäen kotikielenä milloin suomea, milloin puolaa. Tällaisissa olosuhteissa kaikkinainen vertailu on ollut erottamaton osa elämääni. Mahdollisia vertailukohteita löytyy kaikilta elämänalueilta. Suomea ja Puolaa voi vertailla esimerkiksi talven pituuden, kesäyön valoisuuden, väkiluvun, kansannousujen luonteen, kouluarvosanojen, urheilusuoritusten, uskonnon tai yleisen lainkuuliaisuuden suhteen. Vertailu avartaa, sillä se opettaa katsomaan maailmaa useammasta kuin yhdestä näkökulmasta auttaen ymmärtämään erilaisuutta ja välttämään subjektiivisia, arvottavia kannanottoja. Esimerkiksi historian ymmärrykseni on avartunut Puolan vaiheita eläessäni enemmän kuin kaikilla historian oppitunneilla yhteensä.

Vieraan kielen opiskelemiseen kuuluu kielen eri osa-alueiden jatkuva enemmän tai vähemmän tietoinen vertailu oppijan äidinkielen kanssa. Vertailussa etusijalle nou- 
sevat yhtäläisyyksiä helpommin erot muun muassa siksi, että ne aiheuttavat usein oppimisvaikeuksia, joiden vuoksi herää tarve selvittää erojen perimmäinen luonne.

Oman vertailevan tutkimukseni kimmokkeena ovat olleet puolan ja suomen verbien merkitysrakenteen ilmeinen erilaisuus ja siitä juontuvat oppimisvaikeudet. Pääerojen juuret ovat paikannettavissa verbijohdoksiin, joita kummassakin kielessä on varsin runsaasti. Kokemusperäisenä lähtöoletuksenani on ollut, että erojen päälähteenä on puolan verbeille tyypillinen ja suomelle liki vieras prefiksijohto, jossa uusi verbi, prefiksijohdos, tuotetaan lisäämällä prefiksi eli etuliite kantaverbiin, kuten pisać 'kirjoittaa' > prze+pisać 'kirjoittaa (jokin) puhtaaksi', kleić 'liimata' > od+kleić 'irrottaa (jokin) liimattu'. Prefiksilliset verbit ovat yleisiä myös esimerkiksi sellaisissa suomalaisten paremmin tuntemissa kielissä kuin ruotsissa (ut+ställa) ja saksassa (aus+stellen). Germaanisten kielten prefiksilliset verbit eivät kuitenkaan muodosta samalla tavoin produktiivista johtosysteemiä kuin slaavilaisten ja myös balttilaisten kielten prefiksilliset verbijohdokset. Historiallisesti mielenkiintoista on, että prefiksit eivät ole kotiutuneet suomeen systemaattisena sananmuodostuskeinona monen prefiksikielen pitkäaikaisesta ja syvällisestä vaikutuksesta huolimatta (vanhat ja uudemmat germaaniset, balttilaiset ja slaavilaiset vaikutukset). Muistan latinaa koulussa opiskellessani kiinnittäneeni erityistä huomiota prefikseihin ja niiden kantaverbeihinsä tuomiin merkityksiin ja merkitysten siirtymiin ja ajatelleeni, että tämähän on kuin runoa.

Kiinnostus puolan verbiprefiksejä kohtaan heräsi siinä puolan opintojeni vaiheessa, jossa havaitsin, kuinka vaikea suomea äidinkielenä puhuvalle oli oppia hahmottamaan puolan verbien suomen verbien morfosemanttisesta rakenteesta monin tavoin poikkeava merkitysrakenne, niin sanoakseni oppia ajattelemaan puolaksi. Useisiin aivan päivittäiseen puolan kielen käyttöön liittyviin kysymyksiin ei tahtonut löytyä vastausta sen paremmin kieliopeista, sanakirjoista kuin oppikirjoistakaan.

Myöhemmin Helsingin yliopistossa puolaa opettaessani totesin, että suomenkielisten opiskelijoiden suurimpana vaikeutena oli juuri puolan verbiprefiksien ja prefiksillisten verbien korrekti käyttö. Oman kielenkäytön lisäksi vaikeuksia tuotti myös prefiksillisten verbien tulkitseminen oikein etenkin kaunokirjallisissa teksteissä, joita käännöspiirissä yhdessä opiskelijoiden kanssa käänsimme. Syntyi tarve tutkia, mikä puolan verbiprefikseissä ja prefiksillisissä verbeissä tekee niistä niin outoja ja vaikeaselkoisia suomalaisille.

Edetessään tutkimukseni laajeni koskemaan ei ainoastaan puolan prefiksillisiä verbijohdoksia ja niiden merkitysvastineita suomessa vaan puolan ja suomen koko verbinjohtoa ja sen vaikutusta verbileksikon merkitysrakenteeseen, argumenttirakenteeseen sekä leksikalisointistrategioihin. Näin aihe osoittautui laajemmaksi ja myös yleislingvistisesti kiinnostavammaksi kuin alun alkaen olin tajunnutkaan.

Puolan ja suomen verbileksikkoa yhdistää se, että valtaosa verbeistä on johdoksia, joko toisista verbeistä tai nomineista johtimen lisäyksellä tuotettuja verbejä, esimerkiksi

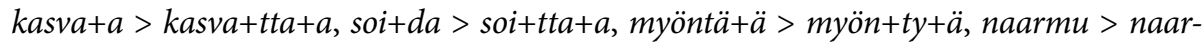
$m u+t t a+a$, jauho + tta $+a$, nokka $>$ nokk $+i+a$, ruoto $>$ ruot $+i+a$, pussi $>$ pussi+tta $+a$. Yhteistä on myös se, että puolan ja suomen verbijohdosten semanttiset pääryhmät ovat samanlaiset, sillä verbijohdokset voidaan jakaa merkitykseltään dynaamisiin muuttamisja muuttumisjohdoksiin sekä muutosta ilmaisemattomiin tilaa tai muutokseen johtama- 
tonta toimintaa kuvaaviin essentiaalijohdoksiin. Tämän lisäksi nominikantaiset johdokset jakaantuvat suomessa ja puolassa samanlaisiin merkitysryhmiin.

Suomea ja puolaa erottavat puolestaan kielten morfosemanttiset johtamiskeinot. Suomessa verbinjohtimet ovat suhteellisen yleismerkityksisiä suffikseja eli jälkiliitteitä, joista enimmät voivat kiinnittyä sekä nomini- että verbikantaan. Puolassa taas verbejä johdetaan sekä suffikseilla, prefikseillä että refleksiivipronominista kehittyneellä puolivapaalla się-morfeemilla (vrt. esim. ruotsin sig, saksan sich) ja niiden yhdistelmillä eli konfikseilla. Puolan johtimista suffiksit kiinnittyvät tyypillisimmin nominikantaan, prefiksit ja się verbikantaan. Prefiksit eroavat suffikseista ennen muuta siinä, että niille on osoitettavissa leksikaalislähtöinen lokaalis-direktionaalinen perusmerkitys (esim. johonkin, jostakin, jonkin ympäri), jonka pohjalta ne ovat kehittyneet monimerkityksisiksi. Vertailu paljastaa, että juuri puolan prefiksien leksikaalinen alkuperä on aiheuttanut puolan ja suomen verbileksikon merkitysrakenteen merkittävimmät erot. Olennaisin niistä on se, miten muutosta ja sen tulosta ilmaistaan verbilekseemeissä.

Suomessa yleismerkityksistä kausatiivista ja ei-kausatiivista muutosta kielentävät ennen muuta $(t) t A$ - ja $U$-johtimet $(m u u+t t a+a, m u u t t+\boldsymbol{u}+a)$. Tulos kielentyy verbijohdokseen kantasanan ollessa nomini tai intransitiiviverbi. Puolassa kausatiivista muutosta ja sen tulosta kielentävät verbikantaan liittyvät leksikaalislähtöiset prefiksit, ei-kausatiivista muutosta puolestaan verbikantainen się-johdin ja kantaverbiltä periytyneet prefiksit. Nominikantaisilla muutosjohdoksilla muutosta ilmaistaan verbilekseemeissä kantanominilla ja/tai niiden resultatiivisilla täydennyksillä.

Prefiksijohdon tuloksena puolan verbileksikon merkitysrakenteelle ovat ominaisia hierarkkiset, porrasteisesti ominaisuuksia periyttävät verbitaksonomiat. Tämä ilmenee muun muassa lähimerkityksisten verbien runsautena. Monijäsenisiä verbitaksonomioita esiintyy etenkin teko- ja niistä johdettujen tapahtumaverbien kantaverbeillä (sellaisilla kuin budzić 'herättää' > budzić się 'herätä) sekä paikan muutosta ilmaisevilla liikeverbeillä (sellaisilla kuin jechać 'ajaa, kulkea kulkunevolla') resultatiivisine prefiksijohdoksineen. Yksittäisillä näihin ryhmiin kuuluvilla kantaverbeillä voi olla toistakymmentäkin prefiksijohdosta, jotka yhdessä kantaverbin kanssa muodostavat rakenteeltaan syvän, hyperonyymi-hyponyymi-suhteessa olevien lähimerkityksisten verbien taksonomian. Hyperonyymina on tällöin kantaverbi ja sen hyponyymeina prefiksijohdokset (esim. verbi piłować 'sahata' ja sen prefiksijohdokset). Suomen verbileksikossa tällaisten verbipesyeiden merkitysvastineena on tavallisesti yksi verbilekseemi tilanteisine täydennyksineen ja määritteineen, kuten sahata jotakin/ jokin irti, poikki, halki, palasiksi, sopivaksi. Verbitaksonomian hyperonyymina voi olla myös prefiksilähtöinen resultatiivinen kattoverbi, jolloin hyponyymeina ovat samaprefiksiset eri kantaverbeistä johdetut verbit, esimerkiksi od(e)- > 'irti' > 'irrottaa': od+ciagnąć 'irrottaa vetämällä, od+ciąć 'irrottaa leikkaamalla', od+piłować 'irrottaa sahaamalla' ja ode+rwać 'irrottaa repäisemällä.

Suomen ja puolan vertailussa mielenkiintoista on, että suomen resultatiiviverbit ovat joko puolan prefiksijohdoksen kantaverbin merkitysvastineita tai verbistyneen prefiksin merkitysvastineita, sillä yhdessä suomen ei-deskriptiivisessä verbilekseemissä ei kielennetä sekä tekotapaa että teon tulosta. 
Prefiksaation synnyttämien verbitaksonomioiden valossa on helppo ymmärtää suomenkielisen puolan oppijan oppimisvaikeuksia. Esimerkiksi sellaisten paikan muutosta ilmaisevien liikeverbien kuin juosta, lentää, uida merkitysvastineina ovat puolassa kantaverbi ja sen viitisentoista eri prefiksillä muodostettua johdosta, jotka ilmaisevat muun muassa, mistä liike alkaa tai mihin se loppuu tai missä määrin määränpää saavutetaan. Nämä ovat seikkoja, joita suomessa ei kielennetä verbiin vaan sen täydennyksiin ja määritteisiin.

Jos joku kysyisi minulta, mitä ovat puolaksi verbit avata, hukkua, hukuttaa, kaataa, kaatua, leikata, mennä, pestä, poistua, pudota, pudottaa, saapua, sahata, sulkea, tulla joutuisin antamaan 15 suomen verbin merkitysvastineiksi arviolta toistasataa puolan verbiä, joista valtaosa olisi prefiksillisiä. Parhaassa tapauksessa (esim. joidenkin liikeverbien yhteydessä) verbillä voi olla jopa 16 prefiksijohdosta, kun prefiksejä on kaikkiaan 17. Verbin merkityksestä riippuen prefiksi voi ilmaista muun muassa verbin aspektia, erilaisia teon tai tapahtuman tuloksia, teko- tai liikkumistapaa, kestoa, määräpaikan saavuttamista, teon intensiivisyysastetta, alkua tai loppua, tuloksen suurta tai pientä määrää, distributiivisuutta, lauseen subjektin tai objektin ominaisuuksia tai laatua. Puolan prefiksilliseen verbijohdokseen sisältyy siis merkittävästi enemmän ja useammanlaista semanttista tietoa asiaintilasta kuin suomen suffikseilla johdettuihin ennen muuta muuttamista $((t) t A$-johdokset, esim. muuttaa) tai muuttumista ( $U$ johdokset, esim. muuttua) ilmaiseviin verbeihin. Puolan prefiksijohdokset ovat hyvä esimerkki niin sanotusta epäsuorasta leksikalisointistrategiasta (conflation; esim. Pajunen 2001: 21), jonka ansiosta asiaintilasta kumuloituu verbiin monenlaista tietoa. Suomen verbikantaiset muutosjohdokset puolestaan ovat esimerkki suorasta strategiasta, jonka mukaisesti verbijohdos kuvaa itse tekoa tai tapahtumaa ja muu semanttinen tieto sisältyy verbin täydennyksiin (subjektiin ja objektiin tai vain subjektiin).

Epäsuoran strategian käyttö tuottaa vaikeuksia sellaiselle kielenoppijalle, jonka äidinkielelle on ominaista suora leksikalisointistrategia. Puolan kielessä käytettävässä strategiassa, jossa verbiin sisällytetään runsaasti tilanteista tietoa muustakin kuin itse teosta tai tapahtumasta, suomalaiselle on hankalaa se, että tilanne pitäisi hahmottaa kokonaisena jo ennen sen kielentämistä. Suomessa puhuja voi rakentaa tilannetta verbin ympärille vähin erin, sillä verbin suhteellisen joustava merkitys rajoittaa vähemmän muita valintoja.

Opin heti ensimmäisenä opiskeluvuotenani professori Oiva Ketosen tieteenfilosofian luennolla, että tieteellisen tutkimuksen perustavoitteena on etsiä ilmiöistä yleistettäviä säännönmukaisuuksia ja luoda niiden pohjalta uutta tietoa. Tämän lektion päätteeksi onkin paikallaan kysyä, mitä uutta tutkimukseni sisältää.

Uutta on vertaileva näkökulma suomen ja puolan verbinjohtoon, joita kumpaakin on kielen sisäisistä lähtökohdista tutkittu paljon. Näkökulma tekee verbinjohdosta paljon muutakin kuin sananmuodostuskeinon, jonka avulla kartutetaan verbisanastoa.

Vertailu tuo esiin ensinnäkin sen, miten ja missä määrin verbinjohto on vaikuttanut verbisanaston aspektuaalisiin ominaisuuksiin ja sen seurauksena tapoihin, joilla lauseen ja tilanteen erityyppistä rajattuutta ilmaistaan. Tämä on tärkeää etenkin siksi, että puolassa verbeihin kieliopillistunutta aspektia ilmaistaan johtimilla.

Toiseksi vertailu paljastaa, miten verbinjohto on vaikuttanut tapoihin, joilla muutosta ja tulosta ilmaistaan puolassa ja suomessa. Toisin sanoen resultatiivisuuden ilmaisemi- 
sen eroilla on juurensa verbinjohdossa. Vertailu myös osoittaa, että suomen ja puolan verbileksikon merkitysrakenteen olennaisena erona ovat puolalle ominaiset resultatiivisten johdosten hierarkkiset taksonomiat. Juuri vertailu on synnyttänyt ideani prefiksien verbistymisestä resultatiivisiksi kattoverbeiksi ja ajatuksen toisesta predikaatiosta.

Vertailu selventää ja täydentää kuvaa suomen ja puolan verbien teonlaatusysteemeistä, ja se paljastaa mielenkiintoisia, nähdäkseni vielä suureksi osaksi tarkemmin tutkimattomia suhteita verbijohdosten aspektuaalisten ja modaalisten ominaisuuksien välillä. Lisäksi se osoittaa, kuinka merkittävä osa verbinjohdolla on suomen ja puolan tyypillisissä leksikalisointistrategioissa eli tavoissa kielentää tilanteita.

Kaiken tämän lisäksi suomen ja puolan verbinjohdon vertailu lisää yleiskielitieteellistä tietoa muun muassa verbien kausatiivisuudesta, kausatiivisuuden suhteesta transitiivisuuteen ja verbien aspektiominaisuuksiin sekä hierarkkisista verbitaksonomioista.

Lopuksi tutkimukseni luo pohjaa sille, miten funktionaalisia verbihakusanoja olisi hyvä rakentaa kaksikielisissä puolan tai yleensäkin slaavilaisen kielen ja jonkin muun kielen sanakirjoissa.

Tutkimukseni yhtenä tärkeänä antina pidän sitä, että se herättää paljon uusia kysymyksiä ja tarjoaa kosolti hyviä tutkimusaiheita, joita yhden työn rajoissa on mahdotonta käsitellä. Aiheen monisäikeisyys on myös tehnyt siitä vaikeasti hallittavan ja (yhden ihmisen) elämää suuremman.

Haluaisin päättää lektioni katkelmaan Jorge Luis Borgesin runosta (1964) nimeltä Kreikkalaisen antologian vähäisemmälle runoilijalle. Suomennos on Pentti Saaritsan. Säkeet sopivat väitöskirjani motoksi.

Loputonta kunniaa soivat jumalat toisille, kaiverruksia mitaleihin, patsaita, säntillisiä elämäkertureita: sinusta, hämärä ystävä, tiedämme vain että kuuntelit jonakin iltana satakieltä.

\section{Lähteet}

Borges, Jorge Luis 1998: Peilin edessä ja takana. Runoja vuosilta 1923-1985. Suomentanut Pentti Saaritsa. Helsinki: WSOY.

Pajunen, Anneli 2001: Argumenttirakenne. Asiaintilojen luokitus ja verbien käyttäytyminen suomen kielessä. Helsinki: Suomalaisen Kirjallisuuden Seura.

Anna Maija Biskupska: Verbi verbistä. Puolan ja suomen johdetun verbileksikon merkitysrakenteen vertailua. Helsinki: Helsingin yliopisto 2018. Väitöskirja on luettavissa osoitteessa http://urn.fi/URN:ISBN:978-951-51-4019.

Kirjoittajan yhteystiedot: anna.laczak@helsinki.fi 